\title{
Assessment of heavy metals concentrations in the soil of Mongla industrial area, Bangladesh
}

\author{
Md. Abu Rayhan Khan ${ }^{\mathbb{D}}$, Mosummath Hosna Ara* ${ }^{\mathbb{D}}$, Palash Kumar Dhar ${ }^{\mathbb{D}}$ \\ Chemistry Discipline, Science Engineering and Technology School, Khulna University, Khulna, Bangladesh
}

\begin{abstract}
Background: Contamination of soil with heavy metals is an alarming issue around the world. Therefore, this study aimed to assess the contamination status of heavy metals in the soil of Mongla industrial area, Bangladesh.

Methods: Soil samples were randomly collected from 20 sites and digested by wet digestion method. The concentrations of heavy metals $(\mathrm{Mn}, \mathrm{Fe}, \mathrm{Cu}, \mathrm{Zn}, \mathrm{Cd}$, and $\mathrm{Pb}$ ) were determined using atomic absorption spectrophotometer (AAS). The quality of soil was assessed based on the contamination factor (CF), geoaccumulation index (Igeo), enrichment factor (EF), and ecological risk index factor (ERIF) analyses. Results: The average concentrations of $\mathrm{Mn}, \mathrm{Fe}, \mathrm{Cu}, \mathrm{Zn}, \mathrm{Cd}$, and $\mathrm{Pb}$ were obtained to be 258.08 \pm 51.61 , $3736.90 \pm 322.17,19.55 \pm 6.49,66.76 \pm 18.32,0.59 \pm 0.13$, and $10.40 \pm 1.49 \mathrm{mg} \mathrm{kg}-1$, respectively, which were below the permissible limit. The highest value of CF $(0.74 \pm 0.16)$, Igeo $(0.35 \pm 0.34)$, EF (24.86 \pm 6.27$)$, and PERIF (22.11 \pm 4.81$)$ was observed for Cd. The pollution of CF, Igeo, EF, and ERIF was classified as very severely polluted, unpolluted to moderately polluted, strongly to extremely polluted, and slightly polluted, respectively, with these heavy metals due to anthropogenic activities. One-way ANOVA indicated a significant difference between $\mathrm{Zn}$ and $\mathrm{Cd}$ concentrations $(P<0.05)$, whereas Pearson correlation showed a positive correlation between $\mathrm{Zn}-\mathrm{Pb}(P=0.01)$ and $\mathrm{Fe}-\mathrm{Zn}(P=0.05)$. Conclusion: There are different classes of contamination with heavy metals in the study area. Therefore, necessary steps should be taken and people's awareness of the soil pollution should be raised.

Keywords: Soil pollution, Heavy metals, Contamination factor, Geoaccumulation index, Enrichment factor, Ecological risk index factor

Citation: Rayhan Khan MA, Ara MH, Dhar PK. Assessment of heavy metals concentrations in the soil of Mongla industrial area, Bangladesh. Environmental Health Engineering and Management Journal 2019; 6(3): 191-202. doi: 10.15171/EHEM.2019.22.
\end{abstract}

\section{Article History:}

Received: 10 April 2019

Accepted: 13 June 2019

ePublished: 19 August 2019

*Correspondence to:

Mosummath Hosna Ara

Email: hosnaara1@gmail.com

\section{Introduction}

Soil is the storehouse of nutrients, minerals, organic and inorganic matters $(1,2)$. But unfortunately, it is being polluted with heavy metals due to natural, as well as anthropogenic activities like smelting procedures, mining, excessive use of wastewater and fertilizers in agricultural fields, and atmospheric deposition from vehicle and industries (3-7). The presence of heavy metals in soil is very dangerous because they are transferred into the food chain (ecosystem) through vegetables and long-term exposure to heavy metals causes different fetal diseases including mental lapse, kidney failure, lung cancer, bone fractures, kidney dysfunction, and hypertension (8-10). At present, soil pollution has become a great global concern. For this reason, the regular monitoring program has been launched to establish a database about the contamination status of heavy metals in soil. Recently, Nessa and Jewel analyzed the concentration of heavy metals in the soil of
Dhaka and reported that the concentrations of $\mathrm{Cu}$ and $\mathrm{Pb}$ were relatively higher than the recommended values (11). In a similar research, Hasnine et al concluded that the level of heavy metals ( $\mathrm{Mn}, \mathrm{Fe}, \mathrm{Cu}$, and $\mathrm{Zn}$ ) in the soil of Dhaka exceeded the standard regulatory limit (12). Fahmida and Rafizul also reported that the soil of waste disposal site of Khulna was mainly contaminated with $\mathrm{Cd}$ and $\mathrm{Pb}$ (13). Islam et al showed that the soil of Tangail industrial area was associated with considerable to very high potential ecological risk (14). In another study, Begum et al determined the concentration of heavy metals in the soil of Bogra city and found that the area was strongly contaminated and uncontaminated to moderately contaminated with the elevated levels of $\mathrm{Cu}$ and Cd, respectively (15).

Recently, Bibak et al assessed the contamination level of sediments in Bushehr province (Iran) based on the geoaccumulation index $\left(\mathrm{I}_{\text {geo }}\right)$ and enrichment factor 
(EF). The higher level of EF was observed for $\mathrm{Fe}$ and $\mathrm{Pb}$, indicating that the sediments contamination was mainly due to anthropogenic activities (16). Ediene and Umoetok examined the concentration of heavy metals in the soil of Cross River State (Nigeria) and reported that the level of $\mathrm{Zn}$ and $\mathrm{Pb}$ in the soil was above the permissible limits, whereas the level of $\mathrm{Cu}$ was within the safe limit (17). Moreover, Begum et al analyzed $\mathrm{I}_{\text {geo }}$ of heavy metals (Fe, $\mathrm{Cu}, \mathrm{Zn}$, and $\mathrm{Pb}$ ) in the soil collected from various localities of Hosur Road, Bangalore (India), and showed that the sampling sites were uncontaminated with $\mathrm{Fe}$ and $\mathrm{Zn}$ and moderately contaminated with $\mathrm{Pb}$ (18). In another study, Saxena and Saxena analyzed the level of heavy metals $(\mathrm{Pb}$, $\mathrm{Cd}, \mathrm{Mn}, \mathrm{Zn}$, and $\mathrm{Cu}$ ) in the soil samples collected from Uttar Pradesh (India). They concluded that the level of $\mathrm{Pb}$ was higher at three sites, whereas the concentration of $\mathrm{Cu}$ in at two sites was higher than the permissible limits (19). Besides, several studies reported the pollution of soil by heavy metals, which is a global concern.

Agricultural products play an important role in Bangladesh economic sector. Although Mongla is an industrial area, the people of this region cultivate different types of agricultural products like vegetables, fishes, crops, and fruits, and supply their products to the local market of Khulna and other parts of Bangladesh. Soil acts as an important resource for the production of these products. If the agricultural products are cultivated in the contaminated soil, the heavy metals may enter the products and consumption of contaminated foods might pose deleterious effects on the human health. Still, there is insufficient information on the contamination status of soil at the southern part of Bangladesh. Due to unrest industrialization in Mongla, different industrial activities, and improper agricultural practices, the soil of this region might be polluted. Therefore, the aim of this study was to determine the concentration of heavy metals in Mongla industrial area and assess the quality of cultivated soil through contamination factor $(\mathrm{CF}), \mathrm{I}_{\text {geo }}, \mathrm{EF}$, and ecological risk index factor (ERIF) analyses, as well as establish a database about the contamination status of heavy metals for future reference.

\section{Materials and Methods}

Mongla is a suburban area in Bagerhat district and located at the bank of Pashur river. It lies between $22^{\circ} 33^{\prime}$ and $21^{\circ} 49^{\prime}$ North latitudes and between $89^{\circ} 32^{\prime}$ and $89^{\circ} 44^{\prime}$ East longitudes. It is also surrounded by Rampal Upazila on the north, by Morrelganj and Sarankhola Upazila on the east, by the Bay of Bengal on the south, and by Dacope Upazila on the west (Figure 1).

Mongla is the second largest port in Bangladesh and 19 different industries are located in this region. Due to unrest industrial activities, different types of industrial effluents, solid waste, hazardous materials are generated and most of them are directly disposed into the soil without proper treatment. Generally, the by-products of

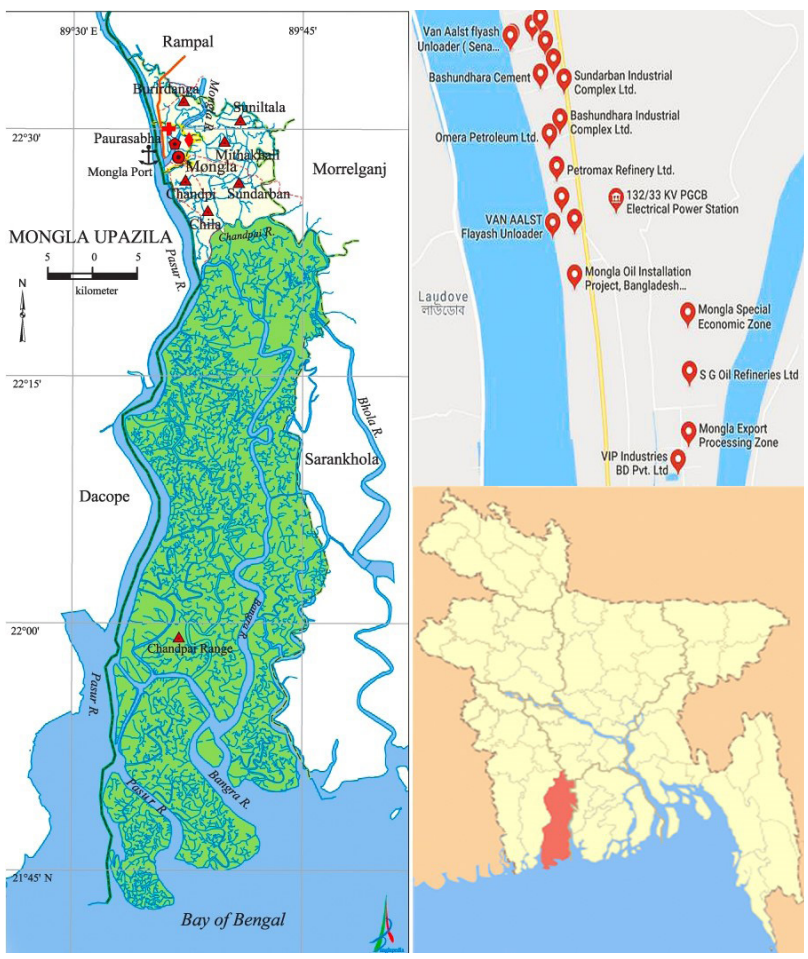

Figure 1. The study area (Mongla, Bangladesh).

cable, petroleum, cement, metallurgy, electroplating, and battery industries contain various heavy metals $(\mathrm{Fe}, \mathrm{Cu}$, $\mathrm{Zn}$ ), (Cu, Zn, Cd, Pb), (Mn, Fe, Cu, Cd), (Cu, Zn, As, Cd, $\mathrm{Pb}),(\mathrm{Cu}, \mathrm{Zn})$, and $(\mathrm{Cu}, \mathrm{Zn}, \mathrm{Cd}, \mathrm{Pb})$, respectively $(20)$. Therefore, the cultivated soil might be contaminated by the industrial sources. A brief description of the different industries located in Mongla industrial area and sampling stations is shown in Table 1.

Basically, the deposition of heavy metals in soil depends on the soil texture. According to a study by Islam et al, the soil of Mongla industrial area can be categorized as silty clay soil, which is composed of 0\%-20\% sand, $40 \%-73 \%$ silt, and $27 \%-40 \%$ clay materials (21).

In this study, soil samples $(n=3 \times 20)$ were randomly collected from 20 relevant sites in Mongla industrial area (Table 1), and the samples were ground into powder form. For each sample analysis, 5:1:1 triacid mixture was prepared by mixing $70 \% \mathrm{HNO}_{3}$ (Merck, Germany), 70\% $\mathrm{H}_{2} \mathrm{SO}_{4}$ (Merck, Germany), and 65\% $\mathrm{HClO}_{4}$ (Merck, Germany). In each beaker containing $1 \mathrm{~g}$ of dried sample, $15 \mathrm{~mL}$ triacid mixture was added. Each mixture was digested at $80^{\circ} \mathrm{C}$ until a transparent solution was obtained. After cooling, the digested samples were filtered and diluted to $50 \mathrm{~mL}$ with deionized water (RCI Labscan Limited) for heavy metal analysis (22). The content of heavy metals (Mn, Fe, $\mathrm{Cu}, \mathrm{Zn}, \mathrm{Pb}$, and $\mathrm{Cd}$ ) in the digested solution was quantified using an atomic absorption spectrophotometer (AAS) (Shimadzu AA-7000) (23). Analysis was replicated and the results were compared with the standard permissible limit. To assess the contamination level of soil and identify the possible contamination sources, the CF, $\mathrm{I}_{\text {geo }}$, EF, and 
Table 1. List of sampling stations and brief description of different industries located in Mongla Upazila, Bagerhat

\begin{tabular}{|c|c|c|}
\hline Sampling Station & Name of Industries & Types of Industries \\
\hline L-01 & Petromax refinery Ltd. & Oil Refinery \\
\hline L-02 & Mongla Oil Installation Project & Oil Refinery \\
\hline L-03 & Shun Shing Edible Oil Ltd. & Oil Refinery \\
\hline L-04 & S G Oil Refineries Ltd. & Oil Refinery \\
\hline L-05 & Omera Petroleum Ltd. & Oil and Gas Refinery \\
\hline L-06 & Bashundhara LP Gas Ltd. & Gas Industry \\
\hline L-07 & Orion LPG Ltd. & Gas Industry \\
\hline L-08 & Sena Kalyan LPG Ltd. & Gas Industry \\
\hline L-09 & KV PGCB Electrical Power Station & Power Station \\
\hline L-10 & Dubai Bangladesh Cement Mills Ltd. & Cement Manufacturer \\
\hline L-11 & Sena Kalyan Cement Factory & Cement Manufacturer \\
\hline L-12 & Bashundhara Cement & Cement Manufacturer \\
\hline L-13 & King Brand Cement & Cement Manufacturer \\
\hline L-14 and L-15 & Holcim Cement Mills Ltd. & Cement Manufacturer \\
\hline L-16 & Sundarban Industrial Complex Ltd. & Industrial Area \\
\hline L-17 & Bashundhara Industrial Complex Ltd. & Industrial Area \\
\hline L-18 & Mongla Export Processing Zone & Industrial Area \\
\hline L-19 & Mongla Special Economic Zone & Industrial Area \\
\hline L-20 & VAN AALST Flyash Unloader & Vacuum Equipment Supplier \\
\hline
\end{tabular}

ERIF were calculated and compared with those reported by similar studies.

$\mathrm{CF}$ is the ratio obtained by dividing the concentration of a specific heavy metal in the soil sample by the background value of that metal. It can be calculated by Eq. (1).

$$
\mathrm{CF}=\frac{\mathrm{C}_{\mathrm{m}}}{\mathrm{C}_{\mathrm{b}}}
$$

where $C_{m}$ is the concentration of heavy metal in soil sample and $C_{b}$ is the background value of the heavy metal. The value of $C_{b}$ can be measured either in precivilization sediments of the study area or taken from the literature. In this study, the background values were taken from literature and the value of $\mathrm{C}_{\mathrm{b}}$ for $\mathrm{Mn}, \mathrm{Fe}, \mathrm{Cu}, \mathrm{Zn}, \mathrm{Cd}$, and $\mathrm{Pb}$ was considered as $850,38000,36,140,0.8$, and $85 \mathrm{mg} \mathrm{kg}^{-1}$, respectively (24-26). Moreover, the soil can be categorized into 10 classes in terms of CF. Uncontaminated (CF $<0.1)$, slightly contaminated $(\mathrm{CF}=0.10-0.25)$, moderately contaminated $(\mathrm{CF}=0.26-0.50)$, severely contaminated $(\mathrm{CF}=0.51-0.75)$, very severely contaminated $(\mathrm{CF}=0.76-1.00)$, slightly polluted $(\mathrm{CF}=1.10-2.00)$, moderately polluted $(\mathrm{CF}=2.10$ $4.00)$, severely polluted $(\mathrm{CF}=4.10-8.00)$, very severely polluted $(\mathrm{CF}=8.10-16.00)$, and excessively polluted $(\mathrm{CF}>$ 16.0) $(24,27)$.

$\mathrm{I}_{\text {geo }}$ is used to evaluate the contamination level of sediment or soil. Generally, the concentration of heavy metals in the studied soil is compared with the concentration of those in pre-industrial levels. $\mathrm{I}_{\text {geo }}$ can be calculated by Eq. (2).

$$
\mathrm{I}_{\text {geo }}=\log _{2}\left(\frac{\mathrm{C}_{\mathrm{n}}}{1.5 \times \mathrm{B}_{\mathrm{n}}}\right)
$$

where $C_{n}$ is the concentration of heavy metal (n) in soil sample and $B_{n}$ is the background value for heavy metal (n). Factor 1.5 indicates the variation of background values for heavy metal in the environment (28-30). According to Legorburu et al, 7 classes of soil were identified in terms of $\mathrm{I}_{\text {geo }}$. Unpolluted $\left(\mathrm{I}_{\text {geo }}<0\right)$, unpolluted to moderately polluted $\left(\mathrm{I}_{\mathrm{geo}}=0 \sim 1\right)$, moderately polluted $\left(\mathrm{I}_{\mathrm{geo}}=1 \sim 2\right)$, moderately to strongly polluted $\left(\mathrm{I}_{\text {geo }}=2 \sim 3\right)$, heavily polluted $\left(\mathrm{I}_{\text {geo }}=3 \sim 4\right)$, strongly to extremely polluted $\left(\mathrm{I}_{\text {geo }}=\right.$ $4 \sim 5)$, and extremely polluted ( $\mathrm{I}_{\text {geo }}>5$ ) (31).

$\mathrm{EF}$ is the measure of anthropogenic and natural sources of heavy metals in soil. In this method, the concentration of heavy metal is compared with that of a reference metal such as $\mathrm{Fe}$ or $\mathrm{Al}$, which can be calculated by Eq. (3).

$$
\mathrm{EF}=\frac{\left(\frac{\mathrm{C}_{\mathrm{M}}}{\mathrm{C}_{\mathrm{Fe}}}\right) \text { Soil }}{\left(\frac{\mathrm{C}_{\mathrm{M}}}{\mathrm{C}_{\mathrm{Fe}}}\right) \text { Background }}
$$

where $\left(C_{M} / C_{F e}\right)$ soil is the ratio of the concentration of heavy metal $\left(\mathrm{C}_{\mathrm{M}}\right)$ to iron $\left(\mathrm{C}_{\mathrm{Fe}}\right)$ in soil samples and $\left(C_{M} /\right.$ $\left.C_{F e}\right)_{\text {Background }}$ is the ratio of the concentration of same metal to iron in the background value $(32,33)$. According to Legorburu et al, soils were categorized into 7 classes based on EF. Unpolluted $(\mathrm{EF}<1.5)$, unpolluted to moderately polluted $(\mathrm{EF}=1.5 \sim 3)$, moderately polluted $(\mathrm{EF}=3 \sim 6)$, moderately to strongly polluted ( $\mathrm{EF}=6 \sim 12)$, strongly polluted $(\mathrm{EF}=12 \sim 24)$, strongly to extremely polluted (EF $=24 \sim 48)$, and extremely polluted (EF > 48) (31). ERIF is considered as an effective tool to express the environmental potential risks of heavy metals in the soil 
and the values are calculated by the following equations:

$\mathrm{ERIF}=\sum$ PERIF

$\mathrm{PERIF}=\frac{\mathrm{T}_{\mathrm{i}} \mathrm{C}_{\mathrm{i}}}{\mathrm{C}_{0}}=\mathrm{Ti} \times \mathrm{CF}$

$\mathrm{CF}=\frac{\mathrm{C}_{\mathrm{i}}}{\mathrm{C}_{0}}$

where $C_{i}$ is the concentration of heavy metals in soil samples, $C_{0}$ is the reference of background value for heavy metals, and $T_{i}$ is the toxic response factor for the heavy metals, which its value for $\mathrm{Mn}, \mathrm{Fe}, \mathrm{Cu}, \mathrm{Zn}, \mathrm{Cd}$, and $\mathrm{Pb}$ is $1,5,5,1,30$, and 5 , respectively (34-37). Soils were categorized into 5 classes based on the PERIF and ERIF values. Slightly contaminated (PERIF $<30$ ), moderately contaminated (30 $\leq$ PERIF $<60)$, strongly contaminated $(60 \leq$ PERIF $<120)$, very strongly contaminated $(120 \leq$ PERIF < 240), and extremely contaminated (PERIF $\geq 240$ ) (38).

Slightly contaminated (ERIF $<40$ ), moderately contaminated $(40 \leq$ ERIF $<80)$, strongly contaminated $(80 \leq$ PERIF $<160)$, very strongly contaminated $(160 \leq$ PERIF < 320), and extremely contaminated (PERIF $\geq 320)$ (38).

\section{Statistical analysis}

The concentrations of different heavy metals in the soil were compared using one-way analysis of variance (ANOVA). Moreover, the inter-element relationship of heavy metals in the soil was determined using Pearson correlation. The mean and standard deviations of metal concentrations, $\mathrm{CF}, \mathrm{I}_{\text {geo }}$, EF, PERIF, and ERIF in the soil were calculated. Data were analyzed using SPSS version 16 software.

\section{Results}

The average concentration of heavy metals in the 20 sampling sites is shown in Table 2. As shown in this table, the average concentration of $\mathrm{Mn}, \mathrm{Fe}, \mathrm{Cu}, \mathrm{Zn}, \mathrm{Cd}$, and $\mathrm{Pb}$ was $258.08 \pm 51.61,3736.90 \pm 322.17,19.55 \pm 6.49,66.76$ $\pm 18.32,0.59 \pm 0.13$, and $10.40 \pm 1.49 \mathrm{mg} \mathrm{kg}^{-1}$, respectively. The concentration of these metals followed the decreasing order of $\mathrm{Fe}>\mathrm{Mn}>\mathrm{Zn}>\mathrm{Cu}>\mathrm{Pb}>\mathrm{Cd}$.

$\mathrm{CF}$ is used to determine the contamination status of soil with heavy metals. CF values of heavy metals in the soil samples are shown in Table 3. The mean values of CF for heavy metals followed the decreasing order of $\mathrm{Fe}>$ $\mathrm{Mn}>\mathrm{Zn}>\mathrm{Pb}>\mathrm{Cu}>\mathrm{Cd}$. Generally, $\mathrm{I}_{\text {geo }}$ measures the contamination level of soil with different heavy metals. The $I_{\text {geo }}$ values of the sampling sites are shown in Table 4. The mean values of $\mathrm{I}_{\text {geo }}$ for heavy metals followed the decreasing order of $\mathrm{Cd}>\mathrm{Zn}>\mathrm{Pb}>\mathrm{Cu}>\mathrm{Mn}>\mathrm{Fe}$. EF is used to determine the magnitude of heavy metals in soil. In this study, iron was considered as the reference metal to evaluate EF factor. The average EF for these heavy metals is shown in Table 5.

Ecological risk assessment of soil is determined by the PERIF and ERIF. Besides, this model is employed to evaluate the soil quality of an environment as well as to assess the degree of soil contamination with multiple heavy metals. PERIF and ERIF value of the sampling sites are shown in Table 6. The mean values of PERIF for heavy

Table 2. Average concentration ( $\mathrm{mg} \mathrm{kg}^{-1}$ ) of heavy metals in sampling sites and their geographical location

\begin{tabular}{|c|c|c|c|c|c|c|c|c|}
\hline Sampling Sites & Longitude & Latitude & Mn & $\mathrm{Fe}$ & $\mathrm{Cu}$ & $\mathrm{Zn}$ & Cd & $\mathrm{Pb}$ \\
\hline L-1 & 89.596001 & 22.481231 & 194.36 & 3867.71 & 30.49 & 50.99 & 0.59 & 9.84 \\
\hline L-2 & 89.598271 & 22.487010 & 178.55 & 3787.38 & 34.63 & 53.70 & 0.61 & 9.00 \\
\hline L-3 & 89.598260 & 22.487063 & 193.30 & 3783.07 & 30.36 & 53.31 & 0.55 & 8.64 \\
\hline L-4 & 89.596754 & 22.491637 & 201.24 & 3979.86 & 17.13 & 54.11 & 0.66 & 10.63 \\
\hline L-5 & 89.596703 & 22.491142 & 221.07 & 3962.69 & 16.16 & 76.67 & 0.83 & 11.78 \\
\hline L-6 & 89.595147 & 22.504722 & 210.08 & 3930.31 & 16.06 & 89.00 & 0.50 & 11.63 \\
\hline L-7 & 89.590528 & 22.502399 & 275.14 & 3947.15 & 19.16 & 62.16 & 0.70 & 11.63 \\
\hline L-8 & 89.591587 & 22.503849 & 283.18 & 3950.74 & 21.69 & 100.54 & 0.51 & 11.09 \\
\hline L-9 & 89.590894 & 22.503177 & 288.11 & 3880.86 & 22.02 & 72.68 & 0.40 & 11.24 \\
\hline L-10 & 89.594435 & 22.504664 & 261.21 & 3976.04 & 19.68 & 62.69 & 0.54 & 9.32 \\
\hline L-11 & 89.588770 & 22.507420 & 225.54 & 3961.38 & 24.75 & 72.67 & 0.32 & 10.02 \\
\hline L-12 & 89.589499 & 22.509362 & 261.25 & 3885.82 & 22.46 & 72.45 & 0.42 & 9.45 \\
\hline L-13 & 89.589628 & 22.511206 & 325.99 & 3779.31 & 12.41 & 53.63 & 0.56 & 10.44 \\
\hline L-14 & 89.589650 & 22.512712 & 349.61 & 3645.77 & 18.33 & 88.45 & 0.74 & 12.42 \\
\hline L-15 & 89.587106 & 22.515993 & 289.28 & 3666.52 & 12.60 & 93.47 & 0.73 & 10.20 \\
\hline L-16 & 89.593084 & 22.505880 & 210.30 & 3957.61 & 15.90 & 89.72 & 0.67 & 11.25 \\
\hline L-17 & 89.591315 & 22.512612 & 307.50 & 3233.49 & 11.57 & 45.29 & 0.69 & 10.53 \\
\hline L-18 & 89.591294 & 22.509004 & 281.61 & 3579.31 & 14.02 & 39.13 & 0.49 & 7.06 \\
\hline L-19 & 89.593245 & 22.510450 & 262.77 & 2782.61 & 19.28 & 41.85 & 0.58 & 8.42 \\
\hline L-20 & 89.574506 & 22.510867 & 341.45 & 3180.39 & 12.37 & 62.66 & 0.70 & 13.33 \\
\hline Range & & & $178.55-349.61$ & 2782.61-3979.86 & $11.57-34.63$ & $39.13-100.54$ & $0.32-0.74$ & $7.06-13.33$ \\
\hline Mean \pm SD & & & $258.08 \pm 51.61$ & $3736.90 \pm 322.17$ & $19.55 \pm 6.49$ & $66.76 \pm 18.32$ & $0.59 \pm 0.13$ & $10.40 \pm 1.49$ \\
\hline Safe limit (39) & & & 270 & 40,000 & 30 & 100 & 1 & 50 \\
\hline
\end{tabular}


Table 3. Average contamination factor (CF) of heavy metals pollution in the soil of twenty sites

\begin{tabular}{|c|c|c|c|c|c|c|}
\hline Location & Mn & $\mathrm{Fe}$ & $\mathrm{Cu}$ & $\mathrm{Zn}$ & $\mathrm{Cd}$ & $\mathrm{Pb}$ \\
\hline L-01 & 0.23 & 0.10 & 0.85 & 0.36 & 0.74 & 0.12 \\
\hline L-02 & 0.21 & 0.10 & 0.96 & 0.38 & 0.76 & 0.11 \\
\hline L-03 & 0.23 & 0.10 & 0.84 & 0.38 & 0.69 & 0.10 \\
\hline L-04 & 0.24 & 0.10 & 0.48 & 0.39 & 0.83 & 0.13 \\
\hline L-05 & 0.26 & 0.10 & 0.45 & 0.55 & 1.04 & 0.14 \\
\hline L-06 & 0.25 & 0.10 & 0.45 & 0.64 & 0.63 & 0.14 \\
\hline L-07 & 0.32 & 0.10 & 0.53 & 0.44 & 0.88 & 0.14 \\
\hline L-08 & 0.33 & 0.10 & 0.60 & 0.72 & 0.64 & 0.13 \\
\hline L-09 & 0.34 & 0.10 & 0.61 & 0.52 & 0.50 & 0.13 \\
\hline L-10 & 0.31 & 0.10 & 0.55 & 0.45 & 0.68 & 0.11 \\
\hline L-11 & 0.27 & 0.10 & 0.69 & 0.52 & 0.40 & 0.12 \\
\hline L-12 & 0.31 & 0.10 & 0.62 & 0.52 & 0.53 & 0.11 \\
\hline L-13 & 0.38 & 0.10 & 0.34 & 0.38 & 0.70 & 0.12 \\
\hline L-14 & 0.41 & 0.10 & 0.51 & 0.63 & 0.93 & 0.15 \\
\hline L-15 & 0.34 & 0.10 & 0.35 & 0.67 & 0.91 & 0.12 \\
\hline L-16 & 0.25 & 0.10 & 0.44 & 0.64 & 0.84 & 0.13 \\
\hline L-17 & 0.36 & 0.09 & 0.32 & 0.32 & 0.86 & 0.12 \\
\hline L-18 & 0.33 & 0.09 & 0.39 & 0.28 & 0.61 & 0.08 \\
\hline L-19 & 0.31 & 0.07 & 0.54 & 0.30 & 0.73 & 0.10 \\
\hline L-20 & 0.40 & 0.08 & 0.34 & 0.45 & 0.88 & 0.16 \\
\hline Mean \pm SD & $0.30 \pm 0.06$ & $0.10 \pm 0.01$ & $0.54 \pm 0.18$ & $0.48 \pm 0.13$ & $0.74 \pm 0.16$ & $0.12 \pm 0.02$ \\
\hline
\end{tabular}

Table 4. Average geoaccumulation index $\left(\mathrm{I}_{\text {geo }}\right)$ of heavy metals pollution in the soil of twenty sites

\begin{tabular}{|c|c|c|c|c|c|c|}
\hline Location & Mn & $\mathrm{Fe}$ & $\mathrm{Cu}$ & $\mathrm{Zn}$ & $\mathrm{Cd}$ & $\mathrm{Pb}$ \\
\hline L-01 & -2.71 & -4.19 & -1.15 & -1.48 & 0.39 & -1.61 \\
\hline L-02 & -2.84 & -4.22 & -0.96 & -1.41 & 0.44 & -1.74 \\
\hline L-03 & -2.72 & -4.23 & -1.15 & -1.42 & 0.29 & -1.80 \\
\hline L-04 & -2.66 & -4.15 & -1.98 & -1.40 & 0.55 & -1.50 \\
\hline L-05 & -2.53 & -4.16 & -2.06 & -0.89 & 0.88 & -1.35 \\
\hline L-06 & -2.60 & -4.17 & -2.07 & -0.68 & 0.15 & -1.37 \\
\hline L-07 & -2.21 & -4.16 & -1.82 & -1.20 & 0.64 & -1.37 \\
\hline L-08 & -2.17 & -4.16 & -1.64 & -0.50 & 0.18 & -1.44 \\
\hline L-09 & -2.15 & -4.19 & -1.62 & -0.97 & -0.17 & -1.42 \\
\hline L-10 & -2.29 & -4.15 & -1.78 & -1.18 & 0.26 & -1.69 \\
\hline L-11 & -2.50 & -4.16 & -1.45 & -0.97 & -0.49 & -1.58 \\
\hline L-12 & -2.29 & -4.19 & -1.59 & -0.98 & -0.10 & -1.67 \\
\hline L-13 & -1.97 & -4.23 & -2.44 & -1.41 & 0.32 & -1.52 \\
\hline L-14 & -1.87 & -4.28 & -1.88 & -0.69 & 0.72 & -1.27 \\
\hline L-15 & -2.14 & -4.27 & -2.42 & -0.61 & 0.70 & -1.56 \\
\hline L-16 & -2.60 & -4.16 & -2.09 & -0.67 & 0.57 & -1.42 \\
\hline L-17 & -2.05 & -4.45 & -2.54 & -1.65 & 0.62 & -1.51 \\
\hline L-18 & -2.18 & -4.31 & -2.27 & -1.86 & 0.12 & -2.09 \\
\hline L-19 & -2.28 & -4.67 & -1.81 & -1.77 & 0.37 & -1.83 \\
\hline L-20 & -1.90 & -4.48 & -2.45 & -1.19 & 0.64 & -1.17 \\
\hline Mean \pm SD & $-2.33 \pm 0.29$ & $-4.25 \pm 0.14$ & $-1.86 \pm 0.46$ & $-1.15 \pm 0.40$ & $0.35 \pm 0.34$ & $-1.55 \pm 0.22$ \\
\hline
\end{tabular}

metals followed the decreasing order of $\mathrm{Cd}>\mathrm{Cu}>\mathrm{Pb}>$ $\mathrm{Fe}>\mathrm{Zn}>\mathrm{Mn}$. The results of Pearson correlation and oneway ANOVA among heavy metals studied are represented in Table 7.

\section{Discussion}

Mongla is considered as the second largest seaport of Bangladesh. Due to rapid industrialization and heavy transport systems, the soil might be contaminated with heavy metals. These metals may enter the food chain when different types of agricultural products are cultivated in the polluted soil. Intake of contaminated foods might cause fatal diseases in human. Therefore, regular monitoring of heavy metals in the sediments is necessary to ensure the quality and safety of the foods. This study was designed to estimate the concentration of heavy metals in the soil and also to assess the level of contamination and its possible sources through different pollution indices. 
Table 5. Average enrichment factor (EF) of heavy metals pollution in the soil of 20 sites

\begin{tabular}{|c|c|c|c|c|c|c|}
\hline Location & $\mathrm{Mn}$ & $\mathrm{Fe}$ & $\mathrm{Cu}$ & $\mathrm{Zn}$ & $\mathrm{Cd}$ & $\mathrm{Pb}$ \\
\hline L-01 & 2.47 & 1.00 & 9.20 & 6.48 & 23.75 & 5.94 \\
\hline L-02 & 2.32 & 1.00 & 10.68 & 6.97 & 25.07 & 5.55 \\
\hline L-03 & 2.51 & 1.00 & 9.37 & 6.93 & 22.63 & 5.33 \\
\hline L-04 & 2.49 & 1.00 & 5.03 & 6.68 & 25.82 & 6.24 \\
\hline L-05 & 2.74 & 1.00 & 4.76 & 9.51 & 32.61 & 6.94 \\
\hline L-06 & 2.63 & 1.00 & 4.77 & 11.13 & 19.80 & 6.91 \\
\hline L-07 & 3.43 & 1.00 & 5.66 & 7.74 & 27.61 & 6.88 \\
\hline L-08 & 3.52 & 1.00 & 6.40 & 12.51 & 20.10 & 6.55 \\
\hline L-09 & 3.65 & 1.00 & 6.62 & 9.21 & 16.04 & 6.76 \\
\hline L-10 & 3.22 & 1.00 & 5.77 & 7.75 & 21.14 & 5.47 \\
\hline L-11 & 2.79 & 1.00 & 7.29 & 9.02 & 12.57 & 5.91 \\
\hline L-12 & 3.30 & 1.00 & 6.74 & 9.17 & 16.83 & 5.68 \\
\hline L-13 & 4.24 & 1.00 & 3.83 & 6.98 & 23.07 & 6.45 \\
\hline L-14 & 4.71 & 1.00 & 5.86 & 11.93 & 31.60 & 7.95 \\
\hline L-15 & 3.87 & 1.00 & 4.01 & 12.53 & 30.99 & 6.50 \\
\hline L-16 & 2.61 & 1.00 & 4.69 & 11.14 & 26.35 & 6.64 \\
\hline L-17 & 4.67 & 1.00 & 4.18 & 6.89 & 33.22 & 7.60 \\
\hline L-18 & 3.86 & 1.00 & 4.57 & 5.37 & 21.31 & 4.61 \\
\hline L-19 & 4.64 & 1.00 & 8.09 & 7.39 & 32.45 & 7.07 \\
\hline L-20 & 5.27 & 1.00 & 4.54 & 9.69 & 34.26 & 9.79 \\
\hline Mean \pm SD & $3.45 \pm 0.90$ & $1.00 \pm 0.00$ & $6.10 \pm 1.95$ & $8.75 \pm 2.17$ & $24.86 \pm 6.27$ & $6.54 \pm 1.11$ \\
\hline
\end{tabular}

Table 6. Average potential ecological risk index factor (PERIF) and ecological risk index factor (ERIF) of heavy metals pollution in the soil samples

\begin{tabular}{|c|c|c|c|c|c|c|c|}
\hline Location & Mn & $\mathrm{Fe}$ & $\mathrm{Cu}$ & $\mathrm{Zn}$ & $\mathrm{Cd}$ & $\mathrm{Pb}$ & ERIF $=\sum$ PERIF \\
\hline L-01 & 0.23 & 0.51 & 4.23 & 0.36 & 22.13 & 0.58 & 28.03 \\
\hline L-02 & 0.21 & 0.50 & 4.80 & 0.38 & 22.88 & 0.53 & 29.30 \\
\hline L-03 & 0.23 & 0.50 & 4.21 & 0.38 & 20.63 & 0.51 & 26.45 \\
\hline L-04 & 0.24 & 0.52 & 2.37 & 0.39 & 24.75 & 0.63 & 28.90 \\
\hline L-05 & 0.26 & 0.52 & 2.24 & 0.55 & 31.13 & 0.69 & 35.39 \\
\hline L-06 & 0.25 & 0.52 & 2.23 & 0.64 & 18.75 & 0.68 & 23.06 \\
\hline L-07 & 0.32 & 0.52 & 2.66 & 0.44 & 26.25 & 0.68 & 30.88 \\
\hline L-08 & 0.33 & 0.52 & 3.01 & 0.72 & 19.13 & 0.65 & 24.35 \\
\hline L-09 & 0.34 & 0.51 & 3.05 & 0.52 & 15.00 & 0.66 & 20.08 \\
\hline L-10 & 0.31 & 0.52 & 2.73 & 0.45 & 20.25 & 0.55 & 24.80 \\
\hline L-11 & 0.27 & 0.52 & 3.43 & 0.52 & 12.00 & 0.59 & 17.33 \\
\hline L-12 & 0.31 & 0.51 & 3.11 & 0.52 & 15.75 & 0.56 & 20.75 \\
\hline L-13 & 0.38 & 0.50 & 1.72 & 0.38 & 21.00 & 0.61 & 24.60 \\
\hline L-14 & 0.41 & 0.48 & 2.54 & 0.63 & 27.75 & 0.73 & 32.54 \\
\hline L-15 & 0.34 & 0.48 & 1.75 & 0.67 & 27.38 & 0.60 & 31.21 \\
\hline L-16 & 0.25 & 0.52 & 2.20 & 0.64 & 25.13 & 0.66 & 29.40 \\
\hline L-17 & 0.36 & 0.43 & 1.60 & 0.32 & 25.88 & 0.62 & 29.21 \\
\hline L-18 & 0.33 & 0.47 & 1.94 & 0.28 & 18.38 & 0.42 & 21.82 \\
\hline L-19 & 0.31 & 0.37 & 2.67 & 0.30 & 21.75 & 0.50 & 25.89 \\
\hline L-20 & 0.40 & 0.42 & 1.71 & 0.45 & 26.25 & 0.78 & 30.02 \\
\hline Mean \pm SD & $0.30 \pm 0.06$ & $0.49 \pm 0.04$ & $2.71 \pm 0.90$ & $0.48 \pm 0.13$ & $22.11 \pm 4.81$ & $0.61 \pm 0.09$ & $26.70 \pm 4.61$ \\
\hline
\end{tabular}

Heavy metals are metals whose density is greater than 5 $\mathrm{g} \mathrm{cm}^{-3}(8)$. These metals are found in the earth crust and can remain in the environment for a long time without any biodegradation (2). Some heavy metals, such as $\mathrm{Mn}$, $\mathrm{Fe}, \mathrm{Cu}$, and $\mathrm{Zn}$, are essential micronutrients for biological functions of the human body. On the other hand, $\mathrm{Cd}$ and $\mathrm{Pb}$ are not essential for a living being, therefore, they are considered as toxic elements in nature.

Among these metals, $\mathrm{Mn}$ is considered as the trace nutrient in the human body but exposure to higher concentration of this metal may disrupt the biological functions in the human body. In this study, the average concentration of Mn $(258.08 \pm 51.00)$ was lower than the permissible limit $\left(270 \mathrm{mg} \mathrm{kg}^{-1}\right)$ (39). But the average concentrations of $\mathrm{Mn}$ in the sampling locations of L-07, 08, 09, 13, 14, 15, 17, 18 , and 20 were $275.14,283.18,288.11,325.99,349.61$, $289.28,307.50,281.61$, and $341.45 \mathrm{mg} \mathrm{kg}^{-1}$, respectively, which were above the safe limit. The elevated levels of $\mathrm{Mn}$ in the soil samples might be due to the disposal of industrial wastes from the cement factory, oil refinery, 
Table 7. Pearson correlation and ANOVA analysis of heavy metals in the soil samples

\begin{tabular}{|c|c|c|c|c|c|c|}
\hline & Mn & $\mathrm{Fe}$ & $\mathrm{Cu}$ & $\mathrm{Zn}$ & $\mathrm{Cd}$ & $\mathrm{Pb}$ \\
\hline \multicolumn{7}{|c|}{ Pearson correlation } \\
\hline $\mathrm{Mn}$ & 1 & & & & & \\
\hline $\mathrm{Fe}$ & -0.435 & 1 & & & & \\
\hline $\mathrm{Cu}$ & $-0.624 *$ & 0.294 & 1 & & & \\
\hline $\mathrm{Zn}$ & 0.090 & $0.448 * *$ & -0.134 & 1 & & \\
\hline $\mathrm{Cd}$ & 0.148 & -0.203 & -0.357 & 0.061 & 1 & \\
\hline $\mathrm{Pb}$ & 0.349 & 0.127 & -0.354 & $0.563^{*}$ & 0.426 & 1 \\
\hline \multicolumn{7}{|l|}{ ANOVA } \\
\hline$P$ value & 0.622 & 0.907 & 0.526 & $0.015^{* * *}$ & & 0.565 \\
\hline F value & 1.233 & 0.317 & 1.872 & $2.835 \mathrm{E}^{3}$ & & 1.570 \\
\hline
\end{tabular}

${ }^{*}$ Correlation is significant at $(P=0.01)$ (2-tailed); ${ }^{*}$ Correlation is significant at $(P=0.05)$ (2-tailed). $* *$ Significant value $(\mathrm{P}<0.05$, One-way ANOVA)

liquid petroleum gas (LPG) industry, etc. Islam et al reported that waste materials from cement, petroleum, and metallurgy process contribute to the disposal of $\mathrm{Mn}$ in the environment (21). Iron is an essential element for the physiological functions in the human body like hemoglobin formation. The tolerable limit of $\mathrm{Mn}$ is beneficial for human but excessive amount of this metal (above $48 \mathrm{mg} \mathrm{kg}^{-1}$ ) may cause gastrointestinal side effects (40). It was found that Fe had the highest average concentration $\left(3736.90 \pm 322.17 \mathrm{mg} \mathrm{kg}^{-1}\right)$ compared to the other heavy metals, though this value was lower than those reported in other similar studies (Table 8). In addition, the mean concentration of Fe was lower than the permissible limits (40000 mg kg-1) in all locations in Bangladesh (39). This study revealed that the average concentration of $\mathrm{Cu}$ in all locations was below the safe limit $\left(30 \mathrm{mg} \mathrm{kg}^{-}\right.$ $\left.{ }^{1}\right)$. But the average concentration of $\mathrm{Cu}$ in $\mathrm{L}-01$ (30.49 mg kg-1), L-02 (34.63 $\mathrm{mg} \mathrm{kg}^{-1}$ ), and L-03 (30.36 $\mathrm{mg} \mathrm{kg}^{-}$ $\left.{ }^{1}\right)$ were slightly higher than the permissible limit. The present study showed that the mean concentration of $\mathrm{Zn}$ in these sampling stations was $66.76 \pm 18.32 \mathrm{mg} \mathrm{kg}^{-1}$, which was lower than the safe limit (100 mg kg-1) (39). The mean concentration of $\mathrm{Zn}$ in all sites except $\mathrm{L}-08$ was below the safe limit. Probably, traffic and other related activities such as liquid petroleum stations, battery packs, oil changes, etc. are responsible for the elevated levels of $\mathrm{Cu}$ and $\mathrm{Zn}$ in soil (35). The average concentration of $\mathrm{Cd}$ in the soil was $0.59 \pm 0.13 \mathrm{mg} \mathrm{kg}^{-1}$, which was below the safe limit (1.00 $\left.\mathrm{mg} \mathrm{kg}^{-1}\right)$ (39) and also lower than the certified value in Bangladesh (41). $\mathrm{Pb}$ and its compounds can easily accumulate in soil due to its low solubility and can remain in the environment for a long time. The mean concentration of $\mathrm{Pb}$ was $10.40 \pm 1.49 \mathrm{mg} \mathrm{kg}^{-1}$, which was lower than the safe limit $\left(50 \mathrm{mg} \mathrm{kg}^{-1}\right)$ (38) but higher than the certified value in Bangladesh (41). The average value of $\mathrm{Pb}$ was higher than that reported in other studies in

Table 8. Comparison of mean heavy metals concentrations (mg kg-1) in the soil samples with other studies

\begin{tabular}{|c|c|c|c|c|c|c|c|}
\hline Study Area & $M n$ & $\mathrm{Fe}$ & $\mathrm{Cu}$ & $\mathrm{Zn}$ & $\mathrm{Pb}$ & Cd & Ref. \\
\hline \multicolumn{8}{|l|}{ National } \\
\hline Bogra & -- & -- & 131.87 & 28.46 & 9.60 & 6.95 & (15) \\
\hline Entire Bangladesh & 669.56 & 37247.15 & 54.29 & 202.81 & 9.4 & 1.26 & (40) \\
\hline Iswardi & 283.50 & 15684.70 & 21.43 & 123.283 & 68.84 & 0.538 & (43) \\
\hline Chittagong & 160.79 & -- & 32.63 & 139.30 & 7.33 & 2.43 & (44) \\
\hline Mymensingh & 182.33 & 24683.33 & 49.10 & 123.19 & 59.39 & -- & (45) \\
\hline Gazipur & -- & -- & 36.18 & 176.66 & 75.00 & 0.20 & (46) \\
\hline Dhaka & -- & -- & 75.04 & 103.34 & 3.84 & 0.52 & (47) \\
\hline Dhaka & -- & 21216 & 37.57 & -- & 50.32 & 0.45 & (48) \\
\hline Dhaka & 125.25 & 455.21 & 12.09 & 3.75 & 2.72 & 0.03 & (49) \\
\hline Jashore & 199.38 & 3773.29 & 11.85 & 49.58 & 12.61 & 0.68 & (50) \\
\hline \multicolumn{8}{|l|}{ International } \\
\hline Manila, Philippines & 1999.00 & -- & 98.70 & 440.00 & 213.60 & 0.57 & (51) \\
\hline Bangkok, Thailand & 340.00 & -- & 41.70 & 118.00 & 47.80 & 0.29 & (52) \\
\hline Palermo, Italy & 519.00 & -- & 63.00 & 138.00 & 202.00 & 0.68 & (53) \\
\hline Sialkot, Pakistan & 17991.62 & -- & 26.85 & 94.2 & 121.4 & 36.80 & (54) \\
\hline Uttar Pradesh, India & -- & -- & 42.90 & 159.90 & 38.30 & -- & (55) \\
\hline Fuyang, China & -- & -- & 40.77 & 159.85 & 40.59 & 0.37 & (56) \\
\hline
\end{tabular}


Bangladesh such as Chittagong, Bogra, and Dhaka (Table 8), which might be due to different sources like vehicle exhaust fumes, dry-cell batteries, sewage effluents, run off of wastes and atmospheric depositions, high vehicular traffic, etc (40). Besides, the application of organic and inorganic fertilizers, fungicides, pesticides, manure, and bio-solids in relevant fields may contribute to the increased level of these heavy metals (42).

The CF values for $\mathrm{Mn}, \mathrm{Fe}, \mathrm{Cu}, \mathrm{Zn}, \mathrm{Cd}$, and $\mathrm{Pb}$ ranged 0.21 $0.41,0.07-0.10,0.32-0.96,0.28-0.72,0.40-1.04$, and 0.08 0.16 , respectively (Table 3 ). In this study, about $70 \%$ of the total areas were moderately contaminated with Mn (27). In addition, the CF values of Fe in some sites were lower than 0.10 , indicating that the sampling sites were slightly contaminated with Fe. Whereas, about $15 \%$ of the total area was severely contaminated with $\mathrm{Cu}, 45 \%$ was severely contaminated by $\mathrm{Zn}, 45 \%$ was very severely contaminated with $\mathrm{Cd}$, and $95 \%$ of the area was slightly contaminated with $\mathrm{Pb}$ (27).

According to Table 4, the mean value of $\mathrm{I}_{\text {geo }}$ showed the decreasing order of $\mathrm{Cd}>\mathrm{Zn}>\mathrm{Pb}>\mathrm{Cu}>\mathrm{Mn}>$ Fe. The $\mathrm{I}_{\text {geo }}$ values were mostly negative in the study area, indicating that the study area was uncontaminated with $\mathrm{Mn}, \mathrm{Fe}$, $\mathrm{Cu}, \mathrm{Zn}$, and $\mathrm{Pb}$. Sampling sites of L-09, L-11, and L-12 were unpolluted with $\mathrm{Cd}$ but other sites were observed unpolluted to moderately polluted (31). The $\mathrm{I}_{\text {geo }}$ values for $\mathrm{Mn}, \mathrm{Fe}, \mathrm{Cu}, \mathrm{Zn}$, and $\mathrm{Pb}$ in all sampling sites were less than zero, indicating that the study sites were unpolluted. The $\mathrm{I}_{\text {geo }}$ values for Cd showed that 17 sites (with exception of L-09, L-11, and L-12) were moderately polluted. In terms of $\mathrm{I}_{\text {geo }}$ value, the concentration of $\mathrm{Cd}$ was higher due to continuous discharge of industrial (petroleum, cement, etc industries) effluents. On the other hand, discharge of these effluents without any chemical treatment can also increase the value of $\mathrm{I}_{\text {geo }}$ for $\mathrm{Cd}$.

In this study, the order of average EF for heavy metals in the soil was as $\mathrm{Cd}>\mathrm{Zn}>\mathrm{Pb}>\mathrm{Cu}>\mathrm{Mn}$ (Table 5). The results revealed that the values of $\mathrm{EF}$ for $\mathrm{Mn}, \mathrm{Cu}, \mathrm{Zn}$, $\mathrm{Cd}$, and $\mathrm{Pb}$ were $2.32-5.27,3.83-10.68,5.37-12.53,12.57$ 34.26 , and 4.61-9.79, respectively. If the value of EF is $\leq$ 2 , it is predicted that heavy metals in the soil come from crustal materials or natural weathering processes. If the EF value becomes greater than 2, anthropogenic activities are responsible for the soil pollution (56). In this study, the EF values were greater than 2, indicating that the concentration of heavy metals in the soil might be due to anthropogenic activities in lieu of natural processes. The results of this study indicated that $40 \%$ of the total area was unpolluted to moderately polluted with Mn but $60 \%$ of the area was moderately polluted with the same metal. Moreover, $40 \%$ of the sampling sites was moderately polluted whereas $60 \%$ was moderately to strongly polluted with $\mathrm{Cu}$. These sites were also polluted with $\mathrm{Zn}$. Strong pollution was observed in $10 \%$ of the sampling sites but $85 \%$ of the sampling sites was moderately to strongly polluted with $\mathrm{Zn}$ while 5\% was moderately polluted with this metal. Besides, pollution index model showed that $50 \%$ of the sampling sites was strongly to extremely polluted while the rest of $50 \%$ sampling sites was strongly polluted with Cd.

The order of PERIF of specific heavy metals in soil was as $\mathrm{Cd}>\mathrm{Cu}>\mathrm{Pb}>\mathrm{Fe}>\mathrm{Zn}>\mathrm{Mn}$ (Table 6). The potential ecological factor of $\mathrm{Mn}, \mathrm{Fe}, \mathrm{Cu}, \mathrm{Zn}, \mathrm{Cd}$, and $\mathrm{Pb}$ was 0.21 $0.41,0.37-0.52,1.60-4.80,0.28-0.72,12.00-31.13$, and $0.42-0.78$, respectively. PERIF values for heavy metals in all sampling sites were less than 30 (PERIF $<30$ ), indicating that these areas were slightly contaminated $(<30)$ with heavy metals studied (38). ERIF for heavy metal ranged from 17.33 to 35.39 (Table 6). The highest and lowest ERIF values were observed in L-11 and L-05, respectively, and its average value was $26.70 \pm 4.61$. In this study, ERIF values for all sampling sites were below 40, indicating the low potential ecological risk in these areas (38). Soil pollution indices (CF, $\mathrm{I}_{\text {geo }}$, EF, PERIF, and ERIF) obtained in this study were compared with those of other studies and are shown in Table 9.

Similar values of ERIF were found in the sediments of Mediterranean, Egypt (36), while the ERIF values in other studies $(37,38)$ were higher than that obtained in the present study. The results of comparison revealed that the sediments of Turag river (Bangladesh) and the soil of coal gangue dump (China) were ecologically threaten by heavy metals.

According to the results of Pearson correlation analysis, a positive inter-element correlation was observed between $\mathrm{Zn}-\mathrm{Pb}(0.01$ level $)$ and $\mathrm{Fe}-\mathrm{Zn}(P=0.05)$, while an inverse correlation was found between $\mathrm{Mn}-\mathrm{Cu}(P=0.01)$ (Table $7)$. However, there was no significant positive or negative correlation among other heavy metals in this region. The correlations among these metal pairs ( $\mathrm{Zn}-\mathrm{Pb}$ and $\mathrm{Fe}-\mathrm{Zn}$ ) indicates that these metal pairs might be originated from common sources. In addition, the relationship predicts that these metal pairs might be identically accumulated in silt clay soil (63). According to ANOVA analysis, a significant relationship was observed between $\mathrm{Cd}$ and $\mathrm{Zn}$ $(P<0.05)$, indicating that the concentration of $\mathrm{Cd}$ and $\mathrm{Zn}$ depend on the soil samples (64).

\section{Conclusion}

According to the results, the level of heavy metals in the soil samples is within the permissible limit. Analysis of various pollution indices (CF, $\mathrm{I}_{\text {geo }}$, EF, PERIF, and ERIF) indicated that the study area is associated with different classes of contaminations with heavy metals. Due to anthropogenic activities, the level of heavy metals is gradually increasing in the soil of Mongla industrial area, Bangladesh. As a result, heavy metals are entering the food chain and causing ecological imbalance. Therefore, regular monitoring of heavy metals should be done to control soil pollution in different areas of Bangladesh. In addition, people's awareness of the harmful impacts of heavy metals in the soil should be raised. 
Table 9. Comparison of soil pollution indices with other similar studies

\begin{tabular}{|c|c|c|c|c|c|c|c|c|}
\hline Parameters & $\mathrm{Mn}$ & $\mathrm{Fe}$ & $\mathrm{Cu}$ & $\mathrm{Zn}$ & $\mathrm{Cd}$ & $\mathrm{Pb}$ & $\sum$ PERIF & References \\
\hline $\mathrm{CF}$ & -- & -- & 0.2 & 0.1 & 5.6 & 0.2 & -- & (33) \\
\hline $\mathrm{I}_{\mathrm{geo}}$ & 0.001 & -- & 0.02 & 0.01 & 0.5 & 0.03 & -- & \\
\hline $\mathrm{EF}$ & 25 & -- & 283 & 92 & 8,598 & 652 & -- & \\
\hline PERIF & -- & -- & 0.8 & 0.1 & 167 & 0.8 & -- & \\
\hline PERIF & 0.44 & -- & 0.91 & 0.23 & 21.52 & 3.01 & -- & (36) \\
\hline ERIF & -- & -- & -- & -- & -- & -- & 26.11 & \\
\hline $\mathrm{CF}$ & -- & -- & 1.58 & 1.08 & 1.40 & 1.64 & -- & (37) \\
\hline $\mathrm{I}_{\text {geo }}$ & -- & -- & 0.06 & -0.53 & -0.26 & 0.12 & -- & \\
\hline PERIF & -- & -- & 7.88 & 1.08 & 42.00 & 8.20 & -- & \\
\hline ERIF & -- & -- & -- & -- & -- & -- & 59.16 & \\
\hline PERIF & -- & -- & 5.24 & 1.27 & 72.92 & 5.39 & & (38) \\
\hline ERIF & -- & -- & -- & -- & -- & -- & 84.82 & \\
\hline CF & -- & 0.001 & -- & 0.02 & -- & 0.04 & -- & $(40)$ \\
\hline Igeo & -- & 0.001 & -- & 0.005 & -- & 0.003 & -- & \\
\hline $\mathrm{EF}$ & -- & -- & -- & 22.46 & -- & 67.35 & -- & \\
\hline $\mathrm{CF}$ & 0.50 & 0.57 & -- & -- & -- & -- & -- & (57) \\
\hline $\mathrm{I}_{\mathrm{geo}}$ & -0.48 & -0.42 & -- & -- & -- & -- & -- & \\
\hline Igeo & -0.24 & -0.13 & -- & -0.15 & -- & -- & -- & (58) \\
\hline $\mathrm{EF}$ & 0.89 & 1.11 & -- & 1.10 & -- & -- & -- & \\
\hline $\mathrm{CF}$ & -- & -- & 0.22 & 0.93 & 7.99 & 2.34 & -- & (59) \\
\hline $\mathrm{I}_{\text {geo }}$ & -- & -- & 0.02 & 0.01 & 1.27 & 0.02 & -- & \\
\hline $\mathrm{I}_{\mathrm{geo}}$ & -- & -- & 0.76 & 0.49 & 1.28 & 1.05 & -- & $(60)$ \\
\hline $\mathrm{EF}$ & -- & -- & 0.13 & 0.30 & 11.31 & 10.66 & -- & \\
\hline CF & -- & 2.98 & 2.33 & 5.93 & -- & -- & -- & (61) \\
\hline $\mathrm{I}_{\text {geo }}$ & -- & 0.30 & 0.19 & 0.60 & -- & -- & -- & \\
\hline PERIF & -- & -- & 11.65 & 5.93 & -- & -- & -- & \\
\hline CF & -- & -- & 0.09 & 0.03 & 6.31 & 0.08 & -- & $(62)$ \\
\hline CF & 0.30 & 0.10 & 0.54 & 0.48 & 0.74 & 0.12 & -- & Present study \\
\hline $\mathrm{I}_{\mathrm{geo}}$ & -2.33 & -4.25 & -1.86 & -1.15 & 0.35 & -1.55 & -- & \\
\hline EF & 3.45 & 1.00 & 6.10 & 8.75 & 24.86 & 6.54 & -- & \\
\hline PERIF & 0.30 & 0.49 & 2.71 & 0.48 & 22.11 & 0.61 & -- & \\
\hline ERIF & -- & -- & -- & -- & -- & -- & 26.70 & \\
\hline
\end{tabular}

\section{Acknowledgments}

The authors would like to thank Research cell, Khulna University for providing financial support.

\section{Ethical issues}

The authors certify that all data collected during the study are presented in this manuscript, and no data from the study have been or will be published separately.

\section{Competing interests}

The authors declare that they have no competing interests.

\section{Authors' Contributions}

MHA (Professor) contributed to the conceptualization, study design, fund acquisition, supervision, and revision of the manuscript. PKD (Assistant Professor) assisted in the manuscript preparation and revision. MARK (MSc research student) contributed to the fieldwork, methodology, data collection and analysis, and the manuscript preparation.

\section{References}

1. Duffus JH. " Heavy metals" a meaningless term? Pure Appl Chem 2002; 74(5): 793-807. doi: 10.1351/ pac200274050793.

2. Addis W, Abebaw A. Determination of heavy metal concentration in soils used for cultivation of Allium sativum L. (garlic) in East Gojjam Zone, Amhara Region, Ethiopia. Cogent Chem 2017; 3(1): 1-12. doi: 10.1080/23312009.2017.1419422.

3. Tlustoš P, Száková J, Vysloužilová M, Pavlíková D, Weger J, Javorská H. Variation in the uptake of arsenic, cadmium, lead, and zinc by different species of willows Salix spp. grown in contaminated soils. Cent Eur J Biol 2007; 2(2): 254-75. doi: 10.2478/s11535-007-0012-3.

4. Bui AT, Nguyen HT, Nguyen MN, Tran TH, Vu TV, Nguyen $\mathrm{CH}$, et al. Accumulation and potential health risks of cadmium, lead and arsenic in vegetables grown near mining sites in Northern Vietnam. Environ Monit 
Assess 2016; 188(9): 525. doi: 10.1007/s10661-0165535-5.

5. Kumar A, Seema. Accumulation of heavy metals in soil and green leafy vegetables, irrigated with wastewater. IOSR J Environ Sci Toxicol Food Technol 2016; 10(10): 8-19. doi: 10.9790/2402-1010020819.

6. Muchuweti M, Birkett JW, Chinyanga E, Zvauya R, Scrimshaw MD, Lester JN. Heavy metal content of vegetables irrigated with mixtures of wastewater and sewage sludge in Zimbabwe: implications for human health. Agric Ecosyst Environ 2006; 112(1): 41-8. doi: 10.1016/j.agee.2005.04.028.

7. Alam GM, Tokunaga S. Chemical extraction of arsenic from contaminated soil. J Environ Sci Health A Tox Hazard Subst Environ Eng 2006; 41(4): 631-43. doi: 10.1080/10934520600575036.

8. Malakootian M, Mortazavi MS, Ahmadi A. Heavy metals bioaccumulation in fish of southern Iran and risk assessment of fish consumption. Environmental Health Engineering and Management Journal 2016; 3(2): 61-8. doi: 10.15171/ehemj.2016.02.

9. Rezaei Raja O, Sobhanardakani S, Cheraghi M. Health risk assessment of citrus contaminated with heavy metals in Hamedan city, potential risk of $\mathrm{Al}$ and $\mathrm{Cu}$. Environmental Health Engineering and Management Journal 2016; 3(3): 131-5. doi: 10.15171/ehem.2016.11.

10. Yazdanbakhsh AR, Abasi MH, Gholami Z, Avazpour M. Evaluation the concentration of mercury, zinc, arsenic, lead and cobalt in the Ilam city water supply network and resources. Environmental Health Engineering and Management Journal 2017; 4(3): 143-8. doi: 10.15171/ ehem.2017.20.

11. Nessa F, Jewel AH. Analysis of soil nutrient and heavy metal concentration in agricultural land of Zirani industrial area, Savar, Dhaka. International Journal of Innovation and Scientific Research 2014; 10(1): 90-8.

12. Hasnine MT, Huda ME, Khatun R, Saadat AH, Ahasan $\mathrm{M}$, Akter S, et al. Heavy metal contamination in agricultural soil at DEPZA, Bangladesh. Environment and Ecology Research 2017; 5(7): 510-6. doi: 10.13189/ eer.2017.050707.

13. Fahmida K, Rafizul IM. An investigation on soil quality and heavy metal levels in soil of Rajbandh waste disposal site at Khulna, Bangladesh. Iranian Journal of Energy and Environment 2017; 8(2): 102-12. doi: 10.5829/ ijee.2017.08.02.02.

14. Islam MS, Kormoker T, Ali MM, Proshad R. Ecological risk analysis of heavy metals toxicity from agricultural soils in the industrial areas of Tangail district, Bangladesh. SF J Environ Earth Sci 2018; 1(2): 1022.

15. Begum K, Mohiuddin KM, Zakir HM, Rahman MM, Hasan MN. Heavy metal pollution and major nutrient elements assessment in the soils of Bogra city in Bangladesh. Can Chem Trans 2014; 2(3): 316-26. doi: 10.13179/canchemtrans.2014.02.03.0088.

16. Bibak M, Sattari M, Agharokh A, Tahmasebi S, Imanpour Namin J. Assessing some heavy metals pollutions in sediments of the northern Persian Gulf (Bushehr province). Environmental Health Engineering and Management Journal 2018; 5(3): 175-9. doi: 10.15171/ ehem.2018.24.
17. Ediene VF, Umoetok SB. Concentration of heavy metals in soils at the municipal dumpsite in Calabar metropolis. Asian J Environ Ecol 2017; 3(2): 1-11. doi: 10.9734/ AJEE/2017/34236.

18. Begum A, Ramaiah M, Harikrishna, Khan I, Veena K. Analysis of heavy metals concentration in soil and litchens from various localities of Hosur road, Bangalore, India. E- J Chem 2009; 6(1): 13-22. doi: $10.1155 / 2009 / 943695$.

19. Saxena R, Saxena DK. Analysis of heavy metal contents in soil and vegetables grown near Gautam Budh Nagar, UP, India. International Journal of Scientific \& Technology Research 2015; 4(10): 259-61.

20. Dara SS, Mishra DD. A Text Book of Environmental Chemistry \& Pollution Control. India: S Chand \& Company; 2004.

21. Islam MA, Hasan MA, Farukh MA. Application of GIS in general soil mapping of Bangladesh. Journal of Geographic Information System 2017; 9(5): 604-621. doi: 10.4236/jgis.2017.95038.

22. Allen SE, Grimshaw HM, Rowland AP. Chemical Analysis. In: Moore PD, Chapman SB, eds. Methods of plant ecology. London: Blackwell Scientific Publication; 1986. p. 285-344.

23. Najah Z, Elsherif KM, Alshtewi M, Attorshi $H$. Phyochemical profile and heavy metals contents of Codium tomentosum and Sargassum honschuchi. J Appl Chem 2015; 4(6): 1821-7. doi: 10.13140/ RG.2.1.3102.3440.

24. Ripin SN, Hasan S, Kamal ML, Hashim NS. Analysis and pollution assessment of heavy metal in soil, perlis. The Malaysian Journal of Analytical Sciences 2014; 18(1): 155-161.

25. Wang Y, Yang Z, Shen Z, Tang Z, Niu J, Gao F. Assessment of heavy metals in sediments from a typical catchment of the Yangtze River, China. Environ Monit Assess 2011; 172(1-4): 407-17. doi: 10.1007/s10661-010-1343-5.

26. Department of Petroleum Resources (DPR). Environmental Guidelines and Standards for the Petroleum Industry in Nigera. Lagos, Nigera (EGASPIN). [cited 2019 Apr 3] Available from: https:// www.dpr.gov.ng/egaspin/.

27. Qingjie G, Jun D, Yunchuan X, Qingfei W, Liqiang Y. Calculating Pollution Indices by Heavy Metals in Ecological Geochemistry Assessment and a Case Study in Parks of Beijing. J China Univ Geosci 2008; 19(3): 230-41. doi: 10.1016/S1002-0705(08)60042-4.

28. Muller G. Index of geoaccumulation in sediments of the Rhine river. GeoJournal 1969; 2(3): 108-18.

29. Addo MA, Affum HA, Botwe BO, Gbadago JK, Acquah SA, Senu JK, et al. Assessment of water quality and heavy metal levels in water and bottom sediment samples from Mokwé Lagoon, Accra, Ghana. Research Journal of Environmental and Earth Sciences 2012; 4(2): 119-30.

30. Praveena SM, Ahmed A, Radojevic M, Abdullah MH, Aris AZ. Factor-cluster analysis and enrichment study of mangrove sediments-an example from Mengkabong, Sabah. Malaysian Journal of Analytical Sciences 2007; 11(2): 421-30.

31. Legorburu I, Rodriguez JG, Borja A, Menchaca I, Solaun O, Valencia V, et al. Source characterization 
and spatio-temporal evolution of the metal pollution in the sediments of the Basque estuaries (Bay of Biscay). Mar Pollut Bull 2013; 66(1-2): 25-38. doi: 10.1016/j. marpolbul.2012.11.016.

32. Franco-Uria A, Lopez-Mateo C, Roca E, FernandezMarcos ML. Source identification of heavy metals in pastureland by multivariate analysis in NW Spain. J Hazard Mater 2009; 165(1-3): 1008-15. doi: 10.1016/j. jhazmat.2008.10.118.

33. Ali Z, Malik RN, Shinwari ZK, Qadir A. Enrichment, risk assessment, and statistical apportionment of heavy metals in tannery-affected areas. Int J Environ Sci Technol 2015; 12(2): 537-50. doi: 10.1007/s13762-0130428-4.

34. Zhang J, Li ZH, Chen J, Wang M, Tao R, Liu D. Assessment of heavy metal contamination status in sediments and identification of pollution source in Daye Lake, Central China. Environ Earth Sci 2014; 72(4): 1279-88. doi: 10.1007/s12665-014-3047-6.

35. Kharkan J, Sayadi MH, Rezaei MR. Investigation of heavy metals accumulation in the soil and pine trees. Environmental Health Engineering and Management Journal 2019; 6(1): 17-25. doi: 10.15171/ehem.2019.03.

36. Soliman NF, Nasr SM, Okbah MA. Potential ecological risk of heavy metals in sediments from the Mediterranean coast, Egypt. J Environ Health Sci Eng 2015; 13: 70. doi: 10.1186/s40201-015-0223-x.

37. Banu Z, Chowdhury MSA, Hossain MD, Nakagami K. Contamination and ecological risk assessment of heavy metal in the sediment of Turag river, Bangladesh: An index analysis approach. J Water Resour Prot 2013; 5(2): 239-48. doi: 10.4236/jwarp.2013.52024.

38. Jiang X, Lu WX, Zhao HQ, Yang QC, Yang ZP. Potential ecological risk assessment and prediction of soil heavymetal pollution around coal gangue dump. Nat Hazards Earth Syst Sci 2014; 14(6): 1599-610. doi: 10.5194/ nhess-14-1599-2014.

39. Mahfuza SS, Jolly YN, Yeasmin S, Satter S, Islam A, Tareq SM. Transfer of heavy metals and radionuclides from soil to vegetables and plants in Bangladesh. In: Hakeem K, Sabir M, Ozturk M, Mermut A, eds. Soil Remediation and Plants: Prospects and Challenges. London: Academic Press, Elsevier; 2014. p. 331-6.

40. Eze OC, Tukura BW, Atolaiye BO, Opaluwa OD. Index model assessment of heavy metal pollution in soils selected from three irrigated farm sites in Fct Abuja, Nigeria. International Journal of Advances in Scientific Research and Engineering 2018; 4(6): 93-105. doi: 10.31695/IJASRE.2018.32758.

41. Tasrina RC, Rowshon A, Mustafizur AM, Rafiqul I, Ali MP. Heavy metals contamination in vegetables and its growing soil. J Environ Anal Chem 2015; 2(3): 142. doi: 10.4172/2380-2391.1000142.

42. Wuana RA, Okieimen FE. Heavy metals in contaminated soils: a review of sources, chemistry, risks and best available strategies for remediation. ISRN Ecol 2011; 2011: 402647. doi: 10.5402/2011/402647.

43. Alamgir M, Islam M, Hossain N, Kibria MG, Rahman MM. Assessment of heavy metal contamination in urban soils of Chittagong city, Bangladesh. International
Journal of Plant \& Soil Science 2015; 7(6): 362-72. doi: 10.9734/IJPSS/2015/18424.

44. Al Zabir A, Zzaman MW, Hossen MZ, Uddin MN, Islam MS, Islam MS. Spatial dissemination of some heavy metals in soil adjacent to Bhaluka industrial area, Mymensingh, Bangladesh. Am J Appl Sci Res 2016; 2(6): 38-47. doi: 10.11648/j.ajasr.20160206.12.

45. Sumi SS. Toxic metallic contamination in industrial wastewater and soils of some selected areas of Gazipur, Bangladesh [dissertation]. Mymensingh: Bangladesh Agricultural University; 2010.

46. Sultana N. Nutrition content and heavy metal contamination in some roadside soils and grasses of Dhaka City, Bangladesh [dissertation]. Mymensingh: Bangladesh Agricultural University; 2010.

47. Mottalib MA, Somoal SH, Shaikh MA, Islam MS. Heavy metal concentrations in contaminated soil and vegetables of tannery area in Dhaka, Bangladesh. Int J Curr Res 2016; 8(5): 30369-73.

48. Ahmad JU, Goni MA. Heavy metal contamination in water, soil, and vegetables of the industrial areas in Dhaka, Bangladesh. Environ Monit Assess 2010; 166(14): 347-57. doi: 10.1007/s10661-009-1006-6.

49. Alam AK, Hossain AB, Hoque S, Chowdhury DA. Heavy metals in wetland soil of greater Dhaka district, Bangladesh. Pollution 2018; 4(1): 129-141. doi: 10.22059/poll.2017.234867.284.

50. Ara MH, Mondal UK, Dhar PK, Uddin MN. Presence of heavy metals in vegetables collected from Jashore, Bangladesh: Human health risk assessment. Journal of Chemical Health Risks 2018; 8(4): 277-87. doi: 10.22034/ jchr.2018.544710.

51. Wilcke W, Müller S, Kanchanakool N, Zech W. Urban soil contamination in Bangkok: heavy metal and aluminium partitioning in topsoils. Geoderma 1998; 86(3-4): 211-28. doi: 10.1016/S0016-7061(98)00045-7.

52. Manta DS, Angelone M, Bellanca A, Neri R, Sprovieri M. Heavy metals in urban soils: a case study from the city of Palermo (Sicily), Italy. Sci Total Environ 2002; 300(1-3): 229-43. doi: 10.1016/S0048-9697(02)00273-5.

53. Malik RN, Jadoon WA, Husain SZ. Metal contamination of surface soils of industrial city Sialkot, Pakistan: a multivariate and GIS approach. Environ Geochem Health 2010; 32(3): 179-91. doi: 10.1007/s10653-0099274-1.

54. Srinivasa Gowd S, Ramakrishna Reddy M, Govil PK. Assessment of heavy metal contamination in soils at Jajmau (Kanpur) and Unnao industrial areas of the Ganga Plain, Uttar Pradesh, India. J Hazard Mater 2010; 174(1-3): 113-21. doi: 10.1016/j.jhazmat.2009.09.024.

55. Zhang XY, Lin FF, Wong MT, Feng XL, Wang K. Identification of soil heavy metal sources from anthropogenic activities and pollution assessment of Fuyang County, China. Environ Monit Assess 2009; 154(1-4): 439-49. doi: 10.1007/s10661-008-0410-7.

56. Almasoud FI, Usman AR, Al-Farraj AS. Heavy metals in the soils of the Arabian Gulf coast affected by industrial activities: analysis and assessment using enrichment factor and multivariate analysis. Arab J Geosci 2015; 8(3): 1691-703. doi: 10.1007/s12517-014-1298-x. 
57. Khan MA, Rashid MM, Jahan S, Hossen K. Trace elements in water and surface sediments of the Bhairab, Rupsha and Pausur river in Bangladesh. Bangladesh Army University of Engineering \& Technology 2017; 1(1): 123-34.

58. Hossain F, Islam MA, Al-Mamun A, Naher K, Khan $\mathrm{R}$, Das $\mathrm{S}$, et al. Assessment of trace contaminants in sediments of the Poshur river nearby Mongla port of Bangladesh. Nucl Sci Appl 2016; 25(1-2): 7-11.

59. Loska K, Wiechula D, Korus I. Metal contamination of farming soils affected by industry. Environ Int 2004; 30(2): 159-65. doi: 10.1016/s0160-4120(03)00157-0.

60. Ololade IA. An assessment of heavy-metal contamination in soils within auto-mechanic workshops using enrichment and contamination factors with geoaccumulation indexes. J Environ Prot 2014; 5(11): 970-82. doi: 10.4236/jep.2014.511098.
61. Sadick A, Owusu AB, Ansah IO, Gaisie E. Assessment of toxic levels of heavy metals in soil in the vicinity of auto mechanic workshop clusters. Int J Sci Res Sci Technol 2016; 2(2): 41-6.

62. Sabo A, Gani AM, Ibrahim AQ. Pollution status of heavy metals in water and bottom sediment of river Delimi in Jos, Nigeria. Am J Environ Prot 2013; 1(3): 47-53. doi: 10.12691/env-1-3-1.

63. Islam MS, Hoque MF. Concentrations of heavy metals in vegetables around the industrial area of Dhaka city, Bangladesh and health risk assessment. Int Food Res J 2014; 21(6): 2121-6.

64. Zhou H, Yang WT, Zhou X, Liu L, Gu JF, Wang WL, et al. Accumulation of heavy metals in vegetable species planted in contaminated soils and the health risk assessment. Int J Environ Res Public Health 2016; 13(3). doi: $10.3390 /$ ijerph13030289. 